\title{
Diversity of Insect Pests and Predators of Cabbage Ecosystem in Different Phonological Stages of Cabbage
}

\author{
Daizy Sarma*, Dilip Kumar Saikia, Anjumoni Devee and Rudra Narayan Borkakati
}

Department of Entomology, AAU, Jorhat, Assam, India

*Corresponding author

Field experiment were carried out in the Experimental Farm, Department of Horticulture, Assam Agricultural University, Jorhat during rabi2017-18 and 2018-19 to study the diversity of insect pests and predators of cabbage ecosystem in different

Keywords

Protein,

carbohydrates,

calcium, iron,

carotene, thiamine,

riboflavin, niacin

Article Info

Accepted:

15 June 2021

Available Online:

10 July 2021 phonological stages of cabbage. Major insect pests recorded during both the crop season from 20 DAP, were cabbage aphid, Brevicoryne brassicae (L.), diamondback moth, Plutella xylostella (L.), cabbage butterfly, Pieris canidia (L.), cutworm, Agrotis ipsilon (Hfn.), cabbage looper Trichoplusiani (Hubner) and flea beetle, Monolepta signata Oliv with minor pests viz., sawfly, Athalia proxima, cabbage head borer, Hellulaundalis (L.), handmaiden moth, Syntomoides imaon (L.), epilachna beetle, Epilachna spp. (L.) and green stink bug, Nezara viridula (L) were also persisted on the crop right from the seedling stage to harvesting of the crop. Six numbers of predators viz., Coccinella transversalis (F.), Maenochilus sexmaculatus C. Septem punctata (L.), Micraspis discolor (F), Harmonia dimidiata (F), Episyrphus belteotus (L.) and one number of predatory spider, Oxyopes spp. were recorded from cabbage ecosystem. The diversity study of insect pests as well as predatorsin different phonological stages of cabbage indicated highest species diversity and evenness during the pre -heading stage of cabbage followed by heading stage whereas, highest species richness was recorded during seedling stage for both the varieties during 201718 and 2018-19.

\section{Introduction}

Cabbage (Brassica oleracea var. capitata L.) is a commercially important cruciferous vegetable. Structurally, cabbage has a short thickened stem surrounded by a series of overlapping expanded leaves which form a compact head (Rice et al., 1986).Cabbage is a good source of protein, carbohydrates, calcium, iron, carotene, thiamine, riboflavin, niacin, as well as vitamin $\mathrm{C}$. It may reduce the risk of some forms of cancer including colorectal cancers. Being a major vegetable crop in India, cabbage is cultivated in about 3.69 lakh hectare with an annual production of 79.49 lakh tonnes. In Assam, the crop is extensively cultivated in all districts as major cash crops in rabi season. Though cabbage has 
various benefits on humans growth and development, but this essential crops are dangerously attacked by several insect pests. The insect pests on cabbage alone causes a yield losses to the extent of 57 to $97 \%$, damaging the crop from planting to till harvesting (Prasad, 1963). Out of which, diamondback moth, Plutella xylostella (L.), cabbage butterfly, Pieris canidia (L.), cutworm, Agrotis ipsilon (Hfn.), flea beetle, Monolepta signata Oliv. are major dangerous to this crop and they damage the cabbage head by making holes in the leaves as well as matured head of the cabbage. Insect play an important role both as major pests and as predators in agro ecosystems. It has been observed that plant- herbivore food webs comprise at least $40 \%$ of global terrestrial biodiversity and most of it concentrated in the tropics (Price, 2002). Phytophagous insects, along with their host plants and natural enemies, may constitute as much as $75 \%$ of the species on the earth and are abundant in all terrestrial ecosystems (Strong et al., 1984). It is therefore, the present investigation was undertaken to assess the diversity of arthropods and their natural enemies at trophic levels of cabbage ecosystem.

\section{Materials and Methods}

The field experiment was conducted in the Experimental Farm, Department of Horticulture, Assam Agricultural University, Jorhat. The cabbage varieties 'Green express' (Hybrid) and 'Golden acre' (HYV) were selected for the present investigation. These are the most popular HYV and hybrid cabbage varieties suitable for all agro-climatic zones of Assam. Monitoring of arthropods fauna was initiated at the seedling emergence of the crop and continued till the harvesting of the crop. Observations on insect pests and natural enemies were recorded at weekly interval starting from 10 days after the transplanting of crop. The collections were made by visual searching method and sweeping net methods. For recording the sucking pests viz., Brevicoryne brassicae L., five plants were randomly selected from each plot, and from each plant, the insects were recorded from three leaves, one from the bottom, one from the middle and one from the top (younger leaves) and expressed in numbers per leaf. The population of other pests, Plutella xylostella (L.) (no. of larva/ plant), Pieris canidia (L.) (no. of larva/ plant), Monolepta signata Oliv. (no of adult/ plant), Agrotis ipsilon (Hfn.) (no. of larva/ plant), Trichoplusia ni (Hubner) (no. of larva/ plant) and coccinelid predators viz., Coccinella transversalis, Coccinella septempunctata and Menochilus sexmaculatus (no. of larva and adult/ plant) also recorded by counting their number on five plants selected randomly and expressed in number per plant. The diversity was calculated by using "Shannon Wiener Index (1949)", species richness index was calculated by using "Margalef index (1958)" and for calculating the evenness of species, "Pielou's Evenness Index (1969)" was used.

\section{Results and Discussion}

\section{Pest and natural enemy complex of cabbage during rabi 2017-18 and 2018-19}

During the course of present investigation, eleven number of insect pests as well as nine numbers of predators were observed on cabbage (Var'Golden acre' and 'Green express') right from transplanting to till the harvest of the crop. Out of these insect pests, some were present in considerable number and thus, were classified as "major" pests of cabbage. Some others were appeared in smaller number were designated as "minor" pests. Various insect pests and predators recorded on cabbage are described below (Tables.1 and 2). 
Table.1 Major insect pest complex associated with cabbage

(var. 'Golden acre' and 'Green express') during 2017-19

\begin{tabular}{|c|c|c|c|c|}
\hline $\begin{array}{c}\text { Common } \\
\text { name }\end{array}$ & Scientific name & Order: Family & Feeding site & Status \\
\hline $\begin{array}{c}\text { Diamond back } \\
\text { moth }\end{array}$ & Plutella xylostella $($ L.) & $\begin{array}{c}\text { Lepidoptera: } \\
\text { Plutellidae }\end{array}$ & Leaf & Major \\
\hline $\begin{array}{c}\text { Cabbage } \\
\text { butterfly }\end{array}$ & Pieris conidia $($ L.) & $\begin{array}{c}\text { Lepidoptera: } \\
\text { Pieridae }\end{array}$ & Leaf & Major \\
\hline Cutworm & Agrotis ipsilon $($ Hfn .) & $\begin{array}{c}\text { Lepidoptera: } \\
\text { Noctuidae }\end{array}$ & Leaf & Major \\
\hline $\begin{array}{c}\text { Cabbage } \\
\text { aphid }\end{array}$ & Brevicoryne brassicae (L.) & $\begin{array}{c}\text { Homoptera: } \\
\text { Aphididae }\end{array}$ & Leaf & Major \\
\hline $\begin{array}{c}\text { Cabbage } \\
\text { looper }\end{array}$ & Trichoplusia ni (Hubner) & $\begin{array}{c}\text { Lepidoptera: } \\
\text { Noctuidae }\end{array}$ & Leaf & Major \\
\hline $\begin{array}{c}\text { Flea beetle } \\
\text { Coleoptera: } \\
\text { Chrysomelidae }\end{array}$ & Monolepta signata Oliv. & Leaf & Major \\
\hline
\end{tabular}

Table.2 Minor insect pest complex associated with cabbage (var. 'Golden acre' and 'Green express') during 2017-19

\begin{tabular}{|c|c|c|c|c|}
\hline Common name & Scientific name & Order: Family & Feeding site & Status \\
\hline Sawfly & Athalia proxima (Klug) & $\begin{array}{l}\text { Hymenoptera: } \\
\text { Tenthredinidae }\end{array}$ & Leaf & Minor \\
\hline $\begin{array}{c}\text { Cabbage head } \\
\text { borer }\end{array}$ & Hellula undalis (L.) & $\begin{array}{l}\text { Lepidoptera: } \\
\text { Pyralidae }\end{array}$ & Leaf & Minor \\
\hline $\begin{array}{l}\text { Handmaiden } \\
\text { moth }\end{array}$ & Syntomoides imaon (L .) & $\begin{array}{l}\text { Lepidoptera: } \\
\text { Erebidae }\end{array}$ & Leaf & Minor \\
\hline Epilachna beetle & Epilachna varivestis (L.) & $\begin{array}{l}\text { Coleoptera: } \\
\text { Coccinellidae }\end{array}$ & Leaf & Minor \\
\hline Green stink bug & Nezara viridula (L.) & $\begin{array}{l}\text { Hemiptera: } \\
\text { Pentatomidae }\end{array}$ & Leaf & Minor \\
\hline
\end{tabular}

Table.3 List of major natural enemies (predators) of cabbage during 2017-19

\begin{tabular}{|c|c|c|c|c|}
\hline \multicolumn{1}{|c|}{ Species } & Order & Family & Prey & Prey Stage \\
\cline { 1 - 1 } Coccinella transversalis (F) & Coleoptera & Coccinellidae & Brevicoryne brassicae & Nymph, adult \\
\hline Menochilus sexmaculatus (F) & Coleoptera & Coccinellidae & Brevicoryne brassicae & Nymph, adult \\
\hline Coccinella septempunctata (L.) & Coleoptera & Coccinellidae & Brevicoryne brassicae & Nymph, adult \\
\hline
\end{tabular}


Table.4 List of minor natural enemies (predators) of cabbage during 2017-19

\begin{tabular}{|c|c|c|c|c|}
\hline Species & Order & Family & Prey & Prey Stage \\
\hline Micraspis discolor (F) & Coleoptera & Coccinellidae & Brevicoryne brassicae & Nymph, adult \\
\hline Harmonia dimidiate $(\mathrm{F})$ & Coleoptera & Coccinellidae & Brevicoryne brassicae & Nymph, adult \\
\hline Episyrphus belteotus (L.) & Diptera & Syrphidae & Brevicoryne brassicae & Nymph, adult \\
\hline Oxyopes spp. & Araneae & Oxyopidae & Brevicoryne brassicae & Nymph, adult \\
\hline Dragon fly & Odonata & Aeshnidae & Brevicoryne brassicae & Nymph, adult \\
\hline Damsel fly & Odonata & Coenagrionidae & Brevicoryne brassicae & Nymph, adult \\
\hline
\end{tabular}

Table.5 Diversity of insect-pests of cabbage in different phonological stages of cabbage (HYV) (2017-19)

\begin{tabular}{|c|c|c|c|c|c|c|c|c|c|}
\hline \multirow[t]{2}{*}{$\begin{array}{l}\text { Crop } \\
\text { stages }\end{array}$} & \multicolumn{2}{|c|}{$\begin{array}{c}\text { Species } \\
\text { Richness (R) }\end{array}$} & \multirow[t]{2}{*}{$\begin{array}{c}\text { Pooled } \\
\text { Mean }\end{array}$} & \multicolumn{2}{|c|}{$\begin{array}{c}\text { Species } \\
\text { Diversity ( } \text { H') }^{\prime}\end{array}$} & \multirow[t]{2}{*}{$\begin{array}{c}\text { Pooled } \\
\text { Mean }\end{array}$} & \multicolumn{2}{|c|}{ Evenness (E) } & \multirow[t]{2}{*}{$\begin{array}{l}\text { Pooled } \\
\text { Mean }\end{array}$} \\
\hline & $\begin{array}{c}2017- \\
18\end{array}$ & $\begin{array}{c}2018- \\
19\end{array}$ & & $\begin{array}{c}2017- \\
18\end{array}$ & $\begin{array}{c}2018- \\
19\end{array}$ & & $\begin{array}{c}2017- \\
18\end{array}$ & $\begin{array}{c}2018 \\
19\end{array}$ & \\
\hline $\begin{array}{c}\text { Seedling } \\
\text { stage }\end{array}$ & 1.51 & 1.57 & 1.54 & 1.75 & 1.65 & 1.70 & 0.97 & 0.92 & 0.94 \\
\hline $\begin{array}{c}\text { Pre- } \\
\text { heading } \\
\text { stage }\end{array}$ & 0.91 & 0.92 & 0.91 & 3.70 & 3.68 & 3.69 & 2.06 & 2.05 & 2.05 \\
\hline $\begin{array}{l}\text { Heading } \\
\text { stage }\end{array}$ & 0.99 & 1.00 & 0.99 & 3.34 & 3.31 & 3.32 & 1.87 & 1.85 & 1.86 \\
\hline
\end{tabular}

Table.6 Diversity of predators of cabbage in different phonological stages of cabbage (HYV) (2017-19)

\begin{tabular}{|c|c|c|c|c|c|c|c|c|c|}
\hline \multirow{2}{*}{$\begin{array}{c}\text { Crop } \\
\text { stages }\end{array}$} & \multicolumn{2}{|c|}{$\begin{array}{c}\text { Species } \\
\text { Richness (R) }\end{array}$} & \multirow[t]{2}{*}{$\begin{array}{l}\text { Pooled } \\
\text { Mean }\end{array}$} & \multicolumn{2}{|c|}{$\begin{array}{c}\text { Species } \\
\left.\text { Diversity ( } \mathbf{H}^{\prime}\right)\end{array}$} & \multirow[t]{2}{*}{$\begin{array}{c}\text { Pooled } \\
\text { Mean }\end{array}$} & \multicolumn{2}{|c|}{ Evenness (E) } & \multirow[t]{2}{*}{$\begin{array}{l}\text { Pooled } \\
\text { Mean }\end{array}$} \\
\hline & $\begin{array}{c}2017- \\
18\end{array}$ & $\begin{array}{c}2018- \\
19\end{array}$ & & $\begin{array}{c}2017- \\
18\end{array}$ & $\begin{array}{c}2018- \\
19\end{array}$ & & $\begin{array}{c}2017- \\
18\end{array}$ & $\begin{array}{c}2018 \\
19\end{array}$ & \\
\hline $\begin{array}{c}\text { Seedling } \\
\text { stage }\end{array}$ & 1.09 & 1.16 & 1.12 & 0.81 & 0.72 & 0.76 & 0.73 & 0.65 & 0.69 \\
\hline $\begin{array}{c}\text { Pre- } \\
\text { heading } \\
\text { stage }\end{array}$ & 0.41 & 0.41 & 0.41 & 3.73 & 3.71 & 3.72 & 3.39 & 3.37 & 3.38 \\
\hline $\begin{array}{c}\text { Heading } \\
\text { stage }\end{array}$ & 0.42 & 0.46 & 0.44 & 3.62 & 3.59 & 3.60 & 3.29 & 3.27 & 3.28 \\
\hline
\end{tabular}


Table.7 Diversity of insect-pests of cabbage in different phonological stages of cabbage (Hybrid) (2017-19)

\begin{tabular}{|c|c|c|c|c|c|c|c|c|c|}
\hline \multirow[t]{2}{*}{$\begin{array}{c}\text { Crop } \\
\text { stages }\end{array}$} & \multicolumn{2}{|c|}{$\begin{array}{c}\text { Species } \\
\text { Richness (R) }\end{array}$} & \multirow[t]{2}{*}{$\begin{array}{c}\text { Pooled } \\
\text { Mean }\end{array}$} & \multicolumn{2}{|c|}{$\begin{array}{c}\text { Species } \\
\text { Diversity ( H') }\end{array}$} & \multirow[t]{2}{*}{$\begin{array}{c}\text { Pooled } \\
\text { Mean }\end{array}$} & \multicolumn{2}{|c|}{ Evenness (E) } & \multirow[t]{2}{*}{$\begin{array}{c}\text { Pooled } \\
\text { Mean }\end{array}$} \\
\hline & $\begin{array}{c}2017- \\
18\end{array}$ & $\begin{array}{c}2018- \\
19\end{array}$ & & $\begin{array}{c}2017- \\
18\end{array}$ & $\begin{array}{c}2018- \\
19\end{array}$ & & $\begin{array}{c}2017- \\
18\end{array}$ & $\begin{array}{c}2018- \\
19\end{array}$ & \\
\hline $\begin{array}{l}\text { Seedling } \\
\text { stage }\end{array}$ & 2.36 & 2.59 & 2.47 & 0.52 & 0.32 & 0.42 & 0.29 & 0.18 & 0.23 \\
\hline $\begin{array}{c}\text { Pre- } \\
\text { heading } \\
\text { stage }\end{array}$ & 0.98 & 0.99 & 0.98 & 3.34 & 3.31 & 3.32 & 1.86 & 1.84 & 1.85 \\
\hline $\begin{array}{l}\text { Heading } \\
\text { stage }\end{array}$ & 1.11 & 1.11 & 1.11 & 2.77 & 2.75 & 2.76 & 1.54 & 1.54 & 1.54 \\
\hline
\end{tabular}

Table.8 Diversity of predators of cabbage in different phonological stages of cabbage (Hybrid) (2017-19)

\begin{tabular}{|c|c|c|c|c|c|c|c|c|c|}
\hline \multirow{2}{*}{$\begin{array}{l}\text { Crop } \\
\text { stages }\end{array}$} & \multicolumn{2}{|c|}{$\begin{array}{c}\text { Species } \\
\text { Richness (R) }\end{array}$} & \multirow[t]{2}{*}{$\begin{array}{l}\text { Pooled } \\
\text { Mean }\end{array}$} & \multicolumn{2}{|c|}{$\begin{array}{c}\text { Species } \\
\left.\text { Diversity ( } \mathrm{H}^{\prime}\right)\end{array}$} & \multirow[t]{2}{*}{$\begin{array}{l}\text { Pooled } \\
\text { Mean }\end{array}$} & \multicolumn{2}{|c|}{ Evenness (E) } & \multirow[t]{2}{*}{$\begin{array}{l}\text { Pooled } \\
\text { Mean }\end{array}$} \\
\hline & $\begin{array}{c}2017- \\
18\end{array}$ & $\begin{array}{c}2018- \\
19\end{array}$ & & $\begin{array}{c}2017- \\
18\end{array}$ & $\begin{array}{c}2018- \\
19\end{array}$ & & $\begin{array}{c}2017- \\
18\end{array}$ & $\begin{array}{c}2018 \\
19\end{array}$ & \\
\hline $\begin{array}{c}\text { Seedling } \\
\text { stage }\end{array}$ & 0.70 & 0.71 & 0.70 & 1.77 & 1.70 & 1.73 & 1.61 & 1.55 & 1.58 \\
\hline $\begin{array}{c}\text { Pre- } \\
\text { heading } \\
\text { stage }\end{array}$ & 0.39 & 0.39 & 0.39 & 3.97 & 3.95 & 3.96 & 3.61 & 3.60 & 3.60 \\
\hline $\begin{array}{c}\text { Heading } \\
\text { stage }\end{array}$ & 0.41 & 0.41 & 0.41 & 3.78 & 3.76 & 3.77 & 3.44 & 3.42 & 3.43 \\
\hline
\end{tabular}

Diversity of insect pests of cabbage in different phonological stages of cabbage (HYV and hybrid variety), 2017-19

The present study revealed that highest species richness of insect pests of HYV and hybrid variety of cabbage was found during seedling stage with 1.54 and 2.47 , respectively followed by heading stage (1.00 and 1.11) and pre- heading stage (0.91 and 0.98). Similarly, highest diversity was observed during preheading stage (3.69 and 3.32) followed by heading stage (3.32 and 2.76) and seedling stage (1.70 and 0.42). However, highest evenness was found during pre- heading stage with 2.05 and 1.85 followed by heading stage (1.86 and 1.54) and seedling stage (0.94and 0.23 ) (Table 5 and 7).

Diversity of predators of cabbage in different phonological stages of cabbage (HYV and hybrid variety), 2017-19

Table 6 and 8 revealed that in case of predators as against HYV and hybrid variety highest species richness was found during seedling stage (1.12 and 0.70) followed by heading stage (0.44 and 0.41) and pre heading stage (0.41 and 0.39). Similarly, highest predators diversity was found during pre- 
heading stage (3.72 and 3.96) followed by heading stage (3.60 and 3.77) and seedling stage (0.76 and 1.73). While, highest evenness was found during pre-heading stage (3.38, $3.60)$, heading stage $(3.28,3.43)$ and seedling stage $(0.69,1.58)$, respectively.

According to, Bakar et al., (2016) in case of insect pests, the untreated control treatment showed the highest diversity index (1.67) at maximum tillering stage and In case of natural enemies, showed the highest diversity index (1.88) at reproductive stage. Anbalagan et al., (2013) studied the natural enemies of insect pests in vegetable crops along with their diversity in Kancheepuram and Tiruvallur Districts, Tamil Nadu. A total of 129 species of predatory and parasitic insects were recorded.

All the natural enemies were grouped into 50 families under eight different orders. Order hymenoptera contained the highest number of families and species. Among the predators, Coccinellidae (ladybird beetles) was found to be the dominant group with high number of species. It was clear that coccinellidae, staphylinidae, carabidae and pentatomidae were the predominant natural enemies throughout the study period and the maximum Shannon-Wiener diversity index was 3.70 during the second season in 2013 while, maximum richness (5.99) was recorded in the second season of 2012. Rahman et al., (2004) also reported that the abundance of insect pest and natural enemies was influenced by different growth stages of rice plant. They observed that the highest abundance was at reproductive stage and lowest was at mid tillering stage, respectively. The results obtained during this study, in respect of the insect pests, are in agreement with studies made by Lal (1975), Devi and Raj (1995), Puri et al., (2000), Bhatia and Gupta (2003), Sharma and Rao (2012), Rai et al., (2014) and Debbarma et al., (2017). Firake et al., (2012) assessed the biodiversity of arthropod fauna in brassicaceous ecosystems of Meghalaya during 2010-12.

\section{Acknowledgement}

The authors are gratefully acknowledges their sincere gratitude to the Director, NBAIR, Bengaluru for identification of natural enemies. The authors are deeply indebted to the Director of Research (Agri.) and Professor and Head, Department of Entomology, Assam Agricultural University, Jorhat-13 for their help during present investigation.

\section{References}

Anbalagan, V., Paulraj, M. G., Ignacimuthu, S., Baskar, K. and Gunasekaran, J. 2013.Natural enemy (ArthropodaInsecta) biodiversity in vegetable crops in Northeastern Tamil Nadu, India. International Letters Natural Scince.53: 28-33.

Bakar, M. A. and Khan, M. M. H. 2016. Diversity of insect pests and natural enemies as influenced by growth stages and pest management practices in rice. Bangladesh Journal of Agricultural Research.41(3): 461-470.

Bhatia, R. and Gupta, D. 2003.Insect and mite pest status of subtropical horticultural crops in Himachal Pradesh. Journal of Insect Science.16(2):1-8.

Debbarma, A., Jayaraj, J., Chandramani, P., Senthil, N., Ananthan, M., Prabakaran, K. 2017. A Survey on Occurrence and Diversity of Insect Pests of Cauliflower in Dindigul and Theni Districts of Tamil Nadu, India. International Journal Current Microbiological Applied Scince.6(9): 2495-2505.

Devi, N. and Raj, D. 1995. Biology and parasitization of diamond back moth, Plutella xylostella L. infesting 
cauliflower in mid hill region of Himachal Pradesh (India), Journal of Entomological Research. 19(1):83-89.

Firake, D. M., Lytan, D. and Behere, G.T.2012. Bio-diversity and seasonal activity of arthropod fauna in Brassicaceous crop ecosystems of Meghalaya, North East India. Molecular Entomology.3(4): 18-22.

Lal, O.P. 1975. A compendium of insect pest of vegetables in India. Bulletin of Entomoogyl.16: 31-56.

Margalef, R. 1958. Information theory in ecology.General Systematics, 3: 36-71.

Pielou, E. C. (1969). Mathematical Ecology.Wiley, New York.pp 374.

Prasad. 1963. Estimation of losses due to insect pest in vegetable crops.Journal of Environmental Ecology, 34(2): 124128.

Price, P. W. 2002. Resource- driven terrestrial interaction webs. Ecological Research.17: 241-47.

Puri, S. N., Murthy, K. S. and Sharma, O. P. 2000. Integrated Pest management in vegetables: Issues and strategies. In. Kalloo, G. and Singh, K. (eds.) Emerging scenario in vegetable research and development. Research Periodicals and book publishing house, Texas, USA, pp. 293-303.
Rahman, M. A., Khan, M. M. H., Hasan, M. F. and Alam, M. M. 2004.Incidence and abundance of insect pests and their natural enemies at different growth stages of rice. Journal of Agricultural Education and Technology.7(1-2): 1924.

Rai, A. B., Halder, J. and Kodandaram, M. H. 2014.Emerging insect pest problems in vegetable crops and their management in India: An appraisal. Pest Management in Horticultural Ecosystem.20(2):113-122.

Rice, R. P., Rice, L. W. and Tindall, H. D. 1986.Fruit and Vegetable Production in Africa. MacMillan Press, London.175-176.

Shannon, C. E. and Wiener, W. 1949.The mathematical theory of communication. University Illinois Press. Urban.p. 324.

Sharma, D., Rao, D. V. 2012. A field study of pest of cauliflower cabbage and okra in some areas of Jaipur. International journal of life sciences biotechnology and pharma research.pp. 121-127.

Strong, D. R., Lawton, J. H. and Southwood, S. R. 1984. Insects on plants: community patterns and mechanisms. Oxford: Blackwell Sci. 313.

\section{How to cite this article:}

Daizy Sarma, Dilip Kumar Saikia, Anjumoni Devee and Rudra Narayan Borkakati. 2021. Diversity of Insect Pests and Predators of Cabbage Ecosystem in Different Phonological Stages of Cabbage. Int.J.Curr.Microbiol.App.Sci. 10(07): 427-433.

doi: https://doi.org/10.20546/ijcmas.2021.1007.047 